Jan Liu*, Kent W. Stewart, Peter P. Pott

\title{
Towards automated and painless venipuncture - vibratory needle insertion techniques
}

\begin{abstract}
The insertion of a needle into soft inhomogeneous tissue is required for many medical procedures. It has been shown that vibratory needle insertion methods have the ability to reduce insertion forces, which are correlated with increased needle placement precision, and reduced frequency and intensity of pain and trauma felt. This paper reviews different vibratory needle insertion methods that have been studied experimentally, addressing vibration generation, vibration frequency and amplitude, and force measurement. Reductions of up to $73 \%$ in peak insertion force $(150 \mathrm{~Hz})$, and $37 \%$ in placement error $(15 \mathrm{~Hz})$ were reported. Additionally, ultrasonic vibration $(84 \mathrm{kHz})$ reduced the force by up to $28 \%$. The results of vibratory insertion show promise, specifically in regard to automated needle devices.
\end{abstract}

Keywords: venipuncture, vibratory needle insertion, insertion force, pain reduction

https://doi.org/10.1515/cdbme-2019-0040

\section{Introduction}

Venipuncture describes the process of inserting a needle into a vein in order to gain intravenous access. One of the most common reasons for venipuncture is blood draw, which is in turn one of the most common invasive procedures overall in health care [1]. However, complications still arise as a successful venipuncture is dependent on clinician skill and patient physiology. An automated and/or robot-assisted venipuncture could improve the procedure to increase patient comfort and reduce erroneous laboratory blood samples. However, before such a device can be made effective, needle insertion forces and placement needs to be studied.

\footnotetext{
*Corresponding author: Jan Liu: Institute of Medical Device Technology, University of Stuttgart, Pfaffenwaldring 9, 70569 Stuttgart, Germany, email: jan.liu@imt.uni-stuttgart.de Kent W. Stewart, Peter P. Pott: Institute of Medical Device Technology, Stuttgart, Germany
}

In general, the needle insertion procedure of a hypodermic needle into a thin sheet of soft tissue can be divided into three phases. In Figure 1, the insertion forces for the different phases, referred to as deflection, cutting, and friction phase, can be seen. The first phase is characterized by a gradual rise in force which corresponds to deflection of the material. At the end of the first phase, the moment of cutting begins which is marked by a sudden change in force $\left(\mathrm{F}_{0}\right)$. The cutting edges of the first lancet create the crack which ends in the maximum insertion force $\left(F_{1}\right)$. The crack is spread open by the second bevel until the needle shaft passes through it, marked by another maximum $\left(F_{2}\right)$. The tip has completely pierced through the tissue, and only friction force is acting on the shaft after that [2-4].

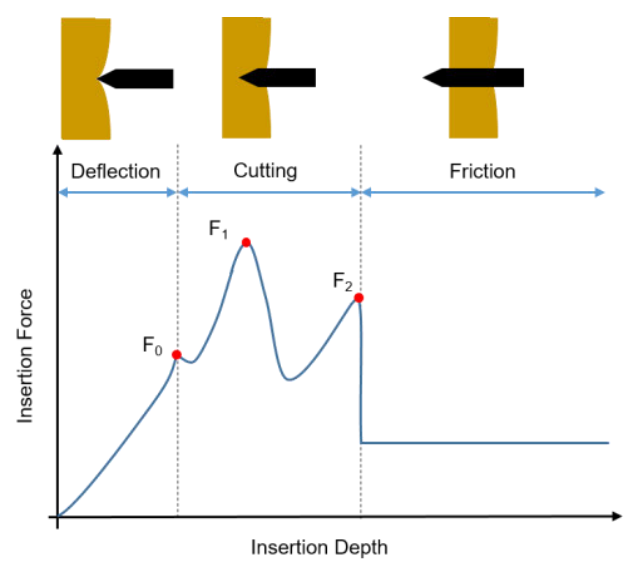

Figure 1 Needle insertion force for the three puncture phases (adopted from [2, 4]).

Vibratory needle insertion has been shown to decrease insertion forces and increase the accuracy of needle placement as a result of less needle bending and tissue deflection [2, 5]. Additionally, lower insertion forces have been shown to reduce the pain felt by patients $[2,6]$. However, currently a wide range of vibration methods have been developed making direct comparison difficult.

This paper reviews nine papers which provide experimental results of a vibratory needle insertion setup. The papers are reviewed specifically in regard to the vibration generation, and frequency and amplitude in order to summarize and evaluate the most effective current methods and future challenges. 


\section{Methods}

Existing literature about vibratory needle insertion was reviewed. The review includes articles that experimentally studied the influence of applying an axial vibration to a needle during insertion and present actual force measurement data obtained during the insertion of a needle into any kind of soft material, either artificial or biological, living or dead. The search was conducted during the end of 2018 using the PubMed database and Google Scholar. Relevant articles were found by considering the title and abstract, and further investigating the tables, figures, and any other available information.

\section{Results}

A summary of the nine studies included in this review is given in Table 1. Needle sizes are given in Birmingham gauge $(\mathrm{G})$ which specifies the external diameter of needles. The higher the gauge, the thinner the needle. For blood draw, hypodermic needles with 21-23G (outer diameter $0.819-0.641 \mathrm{~mm}$ ) are recommended [1]. Three out of the nine reviewed studies used hypodermic needles suitable for blood draw $[2,7,12]$. In addition, six out of the nine reviewed studies used a piezoelectric actuator to generate the vibratory movement [2, 7-11].

Shin-Ei et al. vibrated the needle in the range of 0 to $10 \mathrm{kHz}$ and reported a maximum decrease of $69 \%$ in puncture force using a $10 \mathrm{kHz}$ vibration compared to a nonvibrating insertion. Based on their data, insertion force decreases with an increase in frequency. However, no information was provided on how the force was measured and with what velocity the robotic arm performed the insertion. The authors claim that the viscosity of non-Newtonian interstitial fluid (porcine tissue) is reduced due to an increased shear rate induced by the vibration which, as a result, reduces the overall insertion force [7].

Barnett et al. varied vibration frequency and amplitude for different needle gauges. A linear motor (Dunkermotoren $\mathrm{GmbH}$, Bonndorf, DE) inserted the needle into porcine skin at a constant velocity of $1 \mathrm{~mm} / \mathrm{s}$. A piezoelectric actuator (Physik Instrumente GmbH, Karlsruhe, DE) with a maximum travel length of $90 \mu \mathrm{m}$ provided the vibration. A data acquisition system (PXIe-6361, National Instruments Corporation, Austin, USA) was used to record the force data obtained from a six-axis force sensor (ATI Industrial Automotion Inc., Apex, USA), and control the linear motor and piezoelectric actuator. Experiments showed that the

Table 1: The reviewed articles and their experimental parameters used.

\begin{tabular}{|c|c|c|c|c|c|c|c|c|c|}
\hline $\begin{array}{l}\text { First } \\
\text { Author }\end{array}$ & Ref. & Vibration & Needle & $\begin{array}{c}\text { Linear } \\
\text { insertion }\end{array}$ & Tissue & $\begin{array}{c}\text { Force } \\
\text { measurement }\end{array}$ & $\begin{array}{l}\text { Highest force } \\
\text { reduction }\end{array}$ & $\begin{array}{c}\text { Frequency } \\
\text { range }\end{array}$ & Amplitude \\
\hline Shin-Ei & [7] & Piezoelectric & $\begin{array}{l}\text { Hypodermic } \\
\text { needle } 18 \mathrm{G} \text {, } \\
22 \mathrm{G}\end{array}$ & $\begin{array}{l}\text { Robotic } \\
\text { arm }\end{array}$ & $\begin{array}{l}\text { Porcine } \\
\text { tissue }\end{array}$ & - & $\begin{array}{l}-69 \% \\
\text { puncture force }\end{array}$ & $\begin{array}{l}30 \text { to } \\
10 \mathrm{kHz}\end{array}$ & - \\
\hline Barnett & [2] & Piezoelectric & $\begin{array}{l}\text { Hypodermic } \\
\text { needle } 16 \mathrm{G} \text {, } \\
\text { 18G, } 21 \mathrm{G}, 25 \mathrm{G}\end{array}$ & $\begin{array}{l}\text { Linear } \\
\text { motor }\end{array}$ & $\begin{array}{l}\text { Porcine } \\
\text { skin }\end{array}$ & $\begin{array}{l}\text { 6-DOF F/T } \\
\text { sensor }\end{array}$ & $\begin{array}{l}-30 \text { to }-35 \% \\
\text { puncture force }\end{array}$ & $\begin{array}{l}100 \text { to } \\
2000 \mathrm{~Hz}\end{array}$ & 5 to $50 \mu \mathrm{m}$ \\
\hline Tan & [8] & Piezoelectric & $\begin{array}{l}\text { Bevel-tip needle } \\
18 \mathrm{G}\end{array}$ & $\begin{array}{l}\text { Linear } \\
\text { motor }\end{array}$ & Gelatine & $\begin{array}{l}\text { 6-DOF F/T } \\
\text { sensor }\end{array}$ & - & $\begin{array}{l}50 \text { to } \\
500 \mathrm{~Hz}\end{array}$ & $1 \mu \mathrm{m}$ \\
\hline Huang & [9] & Piezoelectric & $\begin{array}{l}\text { Hypodermic } \\
\text { needle } 27 G\end{array}$ & Ball screw & $\begin{array}{l}\text { Porcine } \\
\text { tissue }\end{array}$ & Load cell & $\begin{array}{l}-28 \% \text { peak } \\
\text { insertion force }\end{array}$ & $84 \mathrm{kHz}$ & - \\
\hline Khalaji & [10] & Piezoelectric & $\begin{array}{l}\text { Brachytherapy } \\
\text { needle } 18 \mathrm{G}\end{array}$ & $\begin{array}{l}\text { Linear } \\
\text { motor }\end{array}$ & $\begin{array}{l}\text { Chicken } \\
\text { tissue }\end{array}$ & $\begin{array}{l}\text { 6-DOF F/T } \\
\text { sensor }\end{array}$ & - & $\begin{array}{l}100 \text { to } \\
1000 \mathrm{~Hz}\end{array}$ & $30 \mu \mathrm{m}$ \\
\hline Izumi & [11] & Piezoelectric & Microneedles & Ball screw & Silicone & Load cell & - & $30 \mathrm{~Hz}$ & - \\
\hline $\mathrm{Bi}$ & {$[5]$} & Voice coil & $\begin{array}{l}\text { Needle with } \\
1 \mathrm{~mm} \varnothing\end{array}$ & Ball screw & Silicone & Load cell & - & $15 \mathrm{~Hz}$ & - \\
\hline Begg & [12] & Voice coil & $\begin{array}{l}\text { Hypodermic } \\
\text { needle } \\
16 G, 21 G\end{array}$ & $\begin{array}{l}\text { Testing } \\
\text { machine }\end{array}$ & $\begin{array}{l}\text { Vyse }{ }^{\circledR} \\
\text { ordnance } \\
\text { gelatine }\end{array}$ & Load cell & - & $\begin{array}{l}100 \mathrm{to} \\
300 \mathrm{~Hz}\end{array}$ & $0-3 \mathrm{~mm}$ \\
\hline Clement & [13] & Voice coil & $\begin{array}{l}\text { Hypodermic } \\
\text { needle } 25 \mathrm{G}\end{array}$ & $\begin{array}{l}\text { Manual } \\
\text { insertion }\end{array}$ & Rat tail & Load cell & $\begin{array}{l}-73 \% \text { peak } \\
\text { insertion force }\end{array}$ & $150 \mathrm{~Hz}$ & $0.6 \mathrm{~mm}$ \\
\hline
\end{tabular}


application of vibration was able to reduce the puncture force by up to $35 \%$ (hypodermic needle $25 \mathrm{G}, 500 \mathrm{~Hz}, 25 \mu \mathrm{m}$ amplitude). Other significant reductions of $33 \%$ (hypodermic needle $18 \mathrm{G}, 100 \mathrm{~Hz}, 25 \mu \mathrm{m}$ amplitude) and $30 \%$ (hypodermic needle $16 \mathrm{G}, 100 \mathrm{~Hz}, 10 \mu \mathrm{m}$ amplitude) in puncture force were reported [2].

Tan et al. [8] examined the exerted force of a $18 \mathrm{G}$ beveltip needle on a gelatin phantom with an insertion velocity of $10 \mathrm{~mm} / \mathrm{s}$, a vibration amplitude of $1 \mu \mathrm{m}$, and different vibration frequencies from 50 to $500 \mathrm{~Hz}$. The exerted force is increased by $17.9 \%$ for a frequency of $500 \mathrm{~Hz}$ compared to a frequency of $50 \mathrm{~Hz}$. This is because the needle tip velocity is composed of the linear insertion velocity and the vibratory velocity which are acting in the same direction. However, the reduction in tissue reaction force was not recorded.

Huang et al. applied an axial vibration at a frequency of $84 \mathrm{kHz}$, generated by a Langevin type piezoelectric transducer, to a commercial $27 \mathrm{G}$ hypodermic needle. The insertion into porcine tissue was driven by a stepper motor (unspecified) at a constant speed of $1.5 \mathrm{~mm} / \mathrm{s}$. The force data measured by a load cell (unspecified) showed a $28 \%$ reduction in maximum insertion force compared to non-vibratory insertion, indicating a reduction of both frictional and cutting force [9].

Khalaji et al. investigated the friction force during needle insertion and carried out experiments advancing and retracting $18 \mathrm{G}$ brachytherapy needles in chicken tissue. The $30 \mu \mathrm{m}$ vibration was generated by two amplified piezoelectric actuators (APA60SM, Cedrat Technologies S.A., Meylan, FR), and the linear insertion movement was performed by a motorized linear stage (T-LSR300B, Zaber Technologies Inc., Vancouver, CA). A 6-DOF force/torque sensor (Nano43, ATI Industrial Automation) recorded the force profiles. Vibration frequencies between 0 and $1000 \mathrm{~Hz}$ were investigated for constant insertion velocities of $5 \mathrm{~mm} / \mathrm{s}$ and $10 \mathrm{~mm} / \mathrm{s}$. It was observed that applying an axial vibration decreases the friction force which was inversely proportional to the vibration frequency. The initial puncture force was not investigated [10].

Izumi et al. aimed at imitating the penetration mechanism of mosquitos into human skin. Self-fabricated silicon microneedles were fixed on a vibration stage driven by a piezoelectric actuator with a maximum amplitude of $100 \mu \mathrm{m}$. The linear insertion movement into silicone rubber at a speed of $0.2 \mathrm{~mm} / \mathrm{s}$ was realized by a servomotor (unspecified) together with a ball screw and a linear slider. The force was measured using a load cell (unspecified) with a rated load of $2 \mathrm{~N}$. Although no quantitative data is given, a positive effect on the puncture force is seen in the figures when applying vibration at a frequency of $30 \mathrm{~Hz}$ [11].
$\mathrm{Bi}$ and Lin [5] focused on targeting accuracy and showed a reduction in placement error, the distance from the target location, of $37 \%$ for an axial vibration of $15 \mathrm{~Hz}$. The vibration was generated by a voice coil motor (VLR0033-0224-00A, Accel Technologies China Co. Ltd., Suzhou, PRC) and applied to a linear movement with a velocity of $2 \mathrm{~mm} / \mathrm{s}$. The linear movement with a travel distance of $200 \mathrm{~mm}$ was performed with a $5 \mathrm{~mm} /$ turn lead screw driven by a stepping motor (BS57HB76-03, Shenzhen Baishan Mechatronics Co. Ltd., Shenzhen, PRC). The displacement was measured by camera (DH-HV3100FC, Daheng Group Inc., Beijing, PRC). Although force data was measured using an unspecified force sensor, no force results were presented. Only one needle size with a diameter of $1.0 \mathrm{~mm}$ was used and the information about the experimental design and the statistical analysis is not given.

Begg and Slocum assessed the effect of axial vibration at different audible frequencies $(100-300 \mathrm{~Hz})$ on the tissue damage and on the force acting directly on the needle tip. Their experimental setup consisted of a $5 \mathrm{~W}$ voice coil from a loudspeaker (135812, Jameco Electronics Ltd., Belmont, USA) driven by a function generator (sinusoidal input amplitudes of 5, 10, and $15 \mathrm{~V}$ ), a power amplifier for the vibration generation, and a universal force testing machine (eXpert 560x, ADMET Inc., Norwood, USA) together with a load cell (SMT1-2.2, ADMET) for the insertion movement and force measurement. For their setup, the biggest decrease in frictional and tip forces, thus the lowest peak insertion forces, were found for a vibration frequency of $150 \mathrm{~Hz}$. The needle oscillated axially with the greatest free amplitude (1-3 $\mathrm{mm}$ for both $16 \mathrm{G}$ and $21 \mathrm{G}$ hypodermic needles) at frequencies around $150 \mathrm{~Hz}$, presumably because the needle system has approached a resonant frequency. Further, they found that cutting of porcine (gracilis) muscle causes less tissue damage when applying a vibration at $150 \mathrm{~Hz}$ compared to $30 \mathrm{kHz}$ [12].

Clement et al. studied the impact on peak insertion forces and on the stress levels of animals when a needle is inserted with a $150 \mathrm{~Hz}$ axial vibration. They used 25G hypodermic needles attached to a custom handheld device for manually performing the insertions. The $150 \mathrm{~Hz}, 0.6 \mathrm{~mm}$ vibration was created by a voice-coil like oscillating movement of a set of magnets inside an alternating magnetic field. Cadaver rat-tail segments were fixed to the tip of a force gauge (FGV-1X, NIDEC-SHIMPO America Corporation, Glendale Heights, USA) which showed that vibration reduced both the peak insertion force (by $73 \%$ ) and peak removal force [13]. 


\section{Discussion}

From the reviewed studies it is clearly visible that presence of vibration reduces insertion force. However, it is difficult to determine a general relationship between the vibration properties and insertion force. Across all of the reviewed studies it can be seen that the maximum reduction in puncture force depends not only on the frequency and amplitude of the vibration but also the needle size, insertion velocity, and tissue. Thus, it is important that future experimental setups have needle sizes and tissue properties, specifically the fracture toughness and shear modulus [2], as close as possible to the intended application. In addition, this also means direct comparison of experimental setups and vibration parameters are difficult.

The largest reductions in insertion force, for a given experimental setup, were seen in Clement et al. [13]. This is likely because of a higher insertion velocity, as insertions were performed manually. Therefore, as a result of the velocity-dependent viscoelastic properties of the tissue, the increased needle insertion velocity results in less tissue deformation. Further, this reduced tissue deformation prior to the uncontrollable crack extensions, due to tissue inhomogeneity, reduces the cutting forces needed [14].

Note all of the reviewed systems were open-loop systems with no feedback and/or control used to ensure the vibratory parameters when entering the tissue. However, as the insertion force may be dependent on shear rate [7], actively controlling the vibration may further reduce potential insertion forces. In addition, it may be beneficial to actively control the vibration amplitude and frequency depending on the stage of insertion or the section of tissue the needle tip is in.

Overall, the reviewed studies suggest that a vibratory insertion can be beneficial for needle insertion by reducing insertion forces which, in turn, increases needle placement accuracy. Further investigation of different vibration parameters, specifically amplitude and frequency, in an in-vivo setting is required to yield more detailed knowledge about the influence on the different insertion forces and phases.

\section{Author Statement}

Research funding: The author state no funding involved. Conflict of interest: Authors state no conflict of interest.

\section{References}

[1] N. Dhingra, WHO guidelines on drawing blood: Best practices in phlebotomy. Geneva, Switzerland: Safe Injection Global Network, World Health Organization, 2010.

[2] A. C. Barnett, "Tissue cutting mechanics of dynamic needle insertion," 2015.

[3] L. Tan et al., "Force Model for Ultrasonic Needle Insertion," Exp Tech, vol. 42, no. 5, pp. 499-508, 2018.

[4] DIN ISO 11040-4 - Vorgefüllte Spritzen - Teil 4: Spritzenzylinder aus Glas für Injektionspräparate und sterilisierte und vormontierte Spritzen zur Abfüllung (ISO 11040-4:2015), 11040-4.

[5] D. Bi and Y. Lin, "Vibrating needle insertion for trajectory optimization," in 7th World Congress on Intelligent Control and Automation, 2008, Chongqing, China, Jun. 2008 - Jun. 2008, pp. 7444-7448.

[6] Egekvist, Bjerring, and Arendt-Nielsen, "Pain and mechanical injury of human skin following needle insertions," European journal of pain (London, England), vol. 3, no. 1, pp. 41-49, 1999.

[7] T. Shin-Ei, K. Yuyama, M. Ujihira, and K. Mabuchi, "Reduction of Insertion Force of Medical Devices into Biological Tissues by Vibration," Japanese journal of medical electronics and biological engineering, vol. 39, no. 4, pp. 292-296, 2001.

[8] L. Tan et al., "Effect of vibration frequency on biopsy needle insertion force," Medical engineering \& physics, vol. 43, pp. 71-76, 2017.

[9] Y. C. Huang, M. C. Tsai, and C. H. Lin, "A piezoelectric vibration-based syringe for reducing insertion force," Materials Science and Engineering Conference Series, vol. 42, 2012.

[10] I. Khalaji, M. Hadavand, A. Asadian, R. V. Patel, and M. D. Naish, "Analysis of needle-tissue friction during vibrationassisted needle insertion," in 2013 IEEE/RSJ International Conference on Intelligent Robots and Systems (IROS): 3-7 Nov. 2013, Tokyo, Japan; conference digest, Tokyo, 2013, pp. 4099-4104.

[11] H. Izumi et al., "Combined Harpoonlike Jagged Microneedles Imitating Mosquito's Proboscis and Its Insertion Experiment with Vibration," IEEJ Trans Elec Electron Eng, vol. 3, no. 4, pp. 425-431, 2008.

[12] N. D. M. Begg and A. H. Slocum, "Audible frequency vibration of puncture-access medical devices," Medical engineering \& physics, vol. 36, no. 3, pp. 371-377, 2014.

[13] R. S. Clement, E. L. Unger, O. M. Ocón-Grove, T. L. Cronin, and M. L. Mulvihill, "Effects of axial vibration on needle vibroinsertion into the tail veins of rats and subsequent serial blood corticosterone levels," Journal of the American Association for Laboratory Animal Science, vol. 55, no. 2, pp. 204-212, 2016.

[14] M. Mahvash and P. E. Dupont, "Mechanics of dynamic needle insertion into a biological material," IEEE transactions on bio-medical engineering, vol. 57 , no. 4, pp. 934-943, 2010. 